\title{
The optimum range of ocean and freshwater quality parameters
}

\author{
Md. Simul Bhuyan ${ }^{1,2 *}$, Istiak Ahamed Mojumder ${ }^{2,3}$ and Monika Das ${ }^{4,5}$ \\ 1Faculty of Marine Sciences and Fisheries, University of Chittagong, Chittagong, Bangladesh \& \\ Bangladesh Research Consultancy Firm, Bangladesh \\ ${ }^{2}$ Bangladesh Research Consultancy Firm, Bangladesh \\ ${ }^{3}$ Department of Zoology, University of Chittagong, Chittagong, Bangladesh \\ ${ }^{4}$ Department of Fisheries, Matshya Bhaban, Dhaka \\ ${ }^{5}$ Department of Fisheries, University of Dhaka, Bangladesh
}

Received: 20 November, 2019

Accepted: 02 March, 2020

Published: 05 March, 2020

*Corresponding author: Md. Simul Bhuyan, Faculty of Marine Sciences and Fisheries, University of Chittagong, Chittagong, Bangladesh \& Bangladesh Research Consultancy Firm, Bangladesh, Tel: +8801754291218; E-mail: simulbhuyan@gmail.com

https://www.peertechz.com

Check for updates

\section{Introduction}

The optimum range of water is very important to determine the quality of water found in ocean and river. Standard is range is very crucial for researchers to know the absolute status of the ocean and river water quality [1-3]. Ocean and river are being polluted day by day. Industrialization, urbanization, oil dumping, and other development activities are responsible for this water quality deterioration. As a result the total ecosystem of the ocean and river is damaged. Consequently, all living organisms are being declined from the water environment. Various pollutants are responsible for this declination. For this, humans also being affected since they consume fish, seaweed,

Table 1: Optimum range for ocean and river water quality parameters.

\begin{tabular}{|c|c|c|}
\hline Physico-chemical parameters & Ocean water & Freshwater/River water \\
\hline $\mathrm{pH}$ & 6.5- 8.5 (US EPA) & 7.0 to $8.50(\mathrm{WHO})$ \\
\hline $\mathrm{EC}$ & $51,500 \mathrm{uS} / \mathrm{cm}$ & $0-800 \mu \mathrm{S} / \mathrm{cm}$ \\
\hline Temperature & -2 to $30^{\circ} \mathrm{C}$ (Average about $17^{\circ} \mathrm{C}$ ) & $5-25^{\circ} \mathrm{C}$ \\
\hline Total Dissolved Solid (TDS) & $35,000 \mathrm{mg} / \mathrm{l}$ & $100-1,000 \mathrm{mg} / \mathrm{L}$ (river)/ 500mg/l (drinking water) \\
\hline Dissolved oxygen (DO) & $90-110 \%$ & $6.5-8 \mathrm{mg} / \mathrm{l} / 7-8 \mathrm{mg} / \mathrm{l}$ \\
\hline Biochemical Oxygen Demand (BOD) & below $1-2 \mathrm{mg} / \mathrm{l}$ & below $1 \mathrm{mg} / \mathrm{l}$ \\
\hline Chemical Oxygen Demand (COD) & 10mg/l (drinking water) & 10mg/l (drinking water) \\
\hline Hardness & $1000 \mathrm{mg} / \mathrm{l}$ & 80 to $100 \mathrm{mg} / \mathrm{l}$ (drinking water) \\
\hline Alkalinity & $>20 \mathrm{mg} / \mathrm{l}$ & $20-200 \mathrm{mg} / \mathrm{l}$ \\
\hline Chloride & about $19,400 \mathrm{mg} / \mathrm{L}$ (a salinity of $35.0 \mathrm{ppt}$ ) & $45-155 \mathrm{mg} / \mathrm{l}$ \\
\hline Salinity & 32-37ppt & $0.5 p p t$ or less \\
\hline Conductivity & $5 \mathrm{~S} / \mathrm{m}$ & 5-50mS/m (drinking water) \\
\hline Phosphate-phosphorus $\left(\mathrm{PO}_{4}-\mathrm{P}\right)$ & - & $0.05 \mathrm{mg} / \mathrm{L}$ \\
\hline Nitrate-nitrogen $\left(\mathrm{NO}_{3}-\mathrm{N}\right)$ & - & $1-10 \mathrm{mg} / \mathrm{L}$ \\
\hline Nitrite-nitrogen $\left(\mathrm{NO}_{2}-\mathrm{N}\right)$ & - & $1 \mathrm{mg} / \mathrm{L}$ \\
\hline Ammonia $\left(\mathrm{NH}_{3}\right)$ & Less than $1 \mathrm{mg} / \mathrm{L}$ & less than $1 \mathrm{mg} / \mathrm{L}$ (US EPA) \\
\hline
\end{tabular}


mussel, oyster and other food items derived from ocean and river. The risks that are related to the drinking water must be evaluated [4-8]. In many countries of the world ocean and river water is being used for human consumption. Water is treated with three objectives: 1 . pure water for people's drinking, 2. to increase appeal to the customer, and 3. increasing water treatment facilities that will be feasible and cost effective to operate $[9,10]$. Optimum range is usually given two (2) values, a recommended value and a maximum permissible limit Table 1.

\section{References}

1. Water Quality Parameters \& Indicators. Link: http://bit.ly/3cw9rl5

2. Chloride and Salinity. Link: http://bit.ly/2PJLTja

3. NOAA (2008) How does the temperature of ocean water vary? Link http://bit.ly/2lkaxma
4. Kumar M, Puri A (2012) A review of permissible limits of drinking water. Indian J Occup Environ Med 16: 40-44. Link: http://bit.ly/39m2j9h

5. Conductivity. Link: http://bit.ly/2Vliycl

6. Nitrates. Link: http://bit.ly/2TIWNOE

7. Link: http://bit.ly/38pesZA

8. Abalos PG (2016) What are the ranges for phosphate and nitrate concentrations in rivers? Link: http://bit.ly/2uRPfcF

9. Scholz M (2006) Wetland Systems to Control Urban Runoff. 360. Link: http://bit.ly/2xbZh9r

10. Water Quality Standard. Link: http://bit.ly/39oZ94r
Discover a bigger Impact and Visibility of your article publication with

\section{Peertechz Publications}

Highlights

* Signatory publisher of ORCID

* Signatory Publisher of DORA (San Francisco Declaration on Research Assessment)

* Articles archived in worlds' renowned service providers such as Portico, CNKI, AGRIS, TDNet, Base (Bielefeld University Library), CrossRef, Scilit, J-Gate etc.

* Journals indexed in ICMJE, SHERPA/ROMEO, Google Scholar etc.

* OAI-PMH (Open Archives Initiative Protocol for Metadata Harvesting)

* Dedicated Editorial Board for every journal

* Accurate and rapid peer-review process

* Increased citations of published articles through promotions

* Reduced timeline for article publication

Submit your articles and experience a new surge in publication services (https://www.peertechz.com/submission).

Peertechz journals wishes everlasting success in your every endeavours.

Copyright: (C) 2020 Bhuyan MS, et al. This is an open-access article distributed under the terms of the Creative Commons Attribution License, which permits unrestricted use, distribution, and reproduction in any medium, provided the original author and source are credited. 